Abdul Mongid (Malaysia), Izah Mohd Tahir (Malaysia)

\title{
Technical and scale efficiency of Indonesian rural banks
}

\begin{abstract}
The existence of the rural bank in the Indonesian' financial market is more pronounced recently than ever especially after the Asian crisis in 1997. The ability of rural banks to shield during the crisis and the state programs to develop small and medium enterprises (SMEs), make the role of rural banks more pivotal. Rural banks begin to fill in the gap of financial services in rural areas. Recently, the issue of efficiency has received attention among academic researchers. This study estimates the technical and scale efficiency of rural banks in Indonesia during the period of 2006 and 2007 by using the non-parametric approach - Data Envelopment Analysis (DEA). The results suggest that the degree of technical efficiency is found to be lower than the degree of scale efficiency which indicates that portion of overall inefficiency is due to producing below the production frontier rather than producing at an inefficient scale. In addition, majority of the banks in the sample exhibit suboptimal scale which imply that output should be expanded to reach the optimal scale.
\end{abstract}

Keywords: rural banks, Data Envelopment Analysis, technical efficiency, scale efficiency, Indonesia.

JEL Classification: C21, H21, E59.

\section{Introduction}

Rural bank is a specific entity in the Indonesian banking system. According to Banking Act \#10, 1998, there are two types of banks. The first is the commercial banks that can provide full services of banking business. The second type is the People Credit Banks (BPR) which can only provide limited banking service such as loan, deposit and they are not allowed to provide service in the payment business. People Credit Bank is known as rural bank as it is mostly operated and service customers in the rural area.

BPR is specific because these banks are the most important providers of financing for micro and small and medium enterprises (MSME) in Indonesia. As rural banks are also operating at local level, it means that their roles are very important for the local economy to develop and grow. This makes the position of rural bank very strategic related to the local economic development. The Governor of Indonesia Central Bank has stressed that the role of rural bank should be enhanced and directed to provide service to the MSME and local economy (Annual Speech, Governor of Indonesia Central Bank, January 2008).

According to Bank Indonesia Report to Parliament (2008), at present, there are about 1,812 rural banks with its office 3,287 all over Indone- sia. Of these, 1,342 (74 percent) are privately owned (limited corporation), 426 (23 percent) local government owned and 44 (3 percent) are cooperative. In terms of regional operation, 67.38 percent are operating in Java Island which is divided into four regions; Jakarta and Surround, West Java, Central Java and East Java. This study is focused on the rural banks in East Java; therefore, the focus is specific to this region. The development of rural banks in East Java can be presented below. Based on East Java Financial Statistics published by Bank Indonesia, Surabaya Office, during 2006, there are 337 rural banks with the total office 440. Seven of these banks are Islamic rural banks. There are 335 rural banks with total office 442 in 2007. Nine of them are Islamic rural banks. Rural bank indicators of Central Bank Office are presented in Table 1.

Studies on rural banks efficiency are considered scarce. As far as we are aware, there is only study that focuses on rural banks efficiency in the Philippines by Desrochers \& Lamberte (2003). Therefore, this study is hoped to fill in the gap and adds to the existing banking efficiency literature.

The objective of this paper is to estimate the technical and scale efficiency of Indonesian rural banks for the period of 2006 and 2007.

Table 1. Rural bank indicators of central bank office in March 2008 (in million rupiahs)

\begin{tabular}{|l|c|c|c|c|}
\hline \multicolumn{1}{|c|}{ Indicators } & Surabaya & Malang & Kediri & Jember \\
\hline Assets & $1,352,256$ & 910,559 & $1,098,080$ & 447,567 \\
\hline Loan & 911,892 & 610,846 & 783,495 & 333,456 \\
\hline Third party funds & 796,927 & 620,863 & 711,836 & 261,014 \\
\hline LDR & $114.43 \%$ & $98.39 \%$ & $110.07 \%$ & $127.75 \%$ \\
\hline Profit & 11,701 & 7,886 & 12,904 & 5,826 \\
\hline
\end{tabular}

Notes: $\mathrm{LDR}=$ Loan Deposit Ratio.

Source: Regional Financial Statistics, Bank Indonesia, Surabaya Office. 
This study employs the non-parametric approach because the main purpose is to estimate the technical efficiency and scale efficiency at the rural bank unit level. This approach is preferred because of several reasons; firstly, this model works well with small dataset. Secondly, it does not require any assumptions to be made on the distribution of inefficiency and thirdly, it does not require a particular functional form on the data in determining the most efficient decision-making units (DMU). However, it has its shortcomings in that it assumes data to be free of measurement error and sensitive to outliers.

This paper is organized as follows. Section 1 discusses the empirical works followed by methodology in Section 2. Section 3 highlights the data and specifications of bank inputs and outputs. This is followed by the findings in Section 4 and the finalSection concludes.

\section{Empirical works}

Basically, all studies on efficiency and productivity at a micro level are based on the assumption laid by Farrell (1957). His contribution highlighted new insights on two issues: how to define efficiency and productivity, and how to calculate the efficiency measures. The fundamental assumption is based on microeconomics assumption on the existence of perfect input-output allocation but to allow for inefficient operations. In this context, inefficiency is defined as a gap of a firm from a production function frontier accepted as the benchmark for efficiency.

In other words, when a firm's actual production point lies on the frontier, it is perfectly efficient. If the production point lies below the frontier, then it is inefficient, then, the ratio of the actual to potential production defining the level of efficiency of the individual firm. Farell divided efficiency into technical efficiency and allocative efficiency. The former reflects the ability of a firm to minimize input use as to produce a given amount of output. The latter reflects the ability of a firm to use inputs in optimal proportions, given their respective prices and the production technology (See Jahanshahloo et. al., 2008, for technical note of Farell, 1957). Together, these two measures represent a total efficiency measure (Coelli, 1996).

However, the implementation of this concept in the banking firms is complicated. According to Resti (1997: 224), how to treat deposits is the main problem. On the one hand, it is argued that they are an input to the production of loans (intermediation, or asset approach). Yet, other lines of reasoning (value added approach, or user cost approach) suggest that deposits are themselves an output, involving the creation of value added, and for which the customers bear an opportunity cost.
Favero \& Papi (1995: 390) argue that there is no simple solution to the problem of output and input specification as reasonable arguments can be made for all approaches. The measures of output used do not take quality into account and as it used balance sheet data; off-balance sheet activities are ignored.

Bulk of literature on banking can be classified into two groups. The first is production and the latter is intermediation approach. Production approach refers to bank producing various outputs such as loan and deposit by incurring cost of production. The input is measured by the cost of production; and excludes the interest expenses. Cost of production includes the costs of physical capital and labor. The output is measured in terms of number of accounts serviced. The intermediation approach considers banks as financial intermediation institution. It is assumed that banks collect funds such as deposits, interbank and other borrowings and then transforming these into loans and other productive assets by incurring the cost of production. The inputs for this approach are deposits and the cost of production. Costs are defined to include both interest expense and total costs of production. The outputs are the volumes of earning assets.

Berger and Humphrey (1997) reviewed on 130 empirical works on bank efficiency over 21 countries to estimate the efficiency of financial institutions. From this study, financial institutions are found to have an average efficiency of around 77 percent with a standard deviation of around 13 percentage point. There variety of efficiency level and standard deviation for within-country studies was higher than international average efficiency.

Hauner (2004), using DEA approach, investigated the difference in efficiency among Germany and Austrian banks. The study applied three efficiency approaches: cost efficiency, scale efficiency, and productivity efficiency. The paper also regresses inefficiency on explanatory variables. The study concluded that there was no evidence for average productivity responding to deregulation over the period studied. In terms of type of bank, stateowned banks are found to be more cost-efficient due to the ability to access cheap funds from public and government sources. In contrast to other study, cooperative banks have the same cost-efficient level as private banks. Similar to other works, an increase in economies of scale increased efficiency. Banks that actively involved in contractual trading for funds are more cost-efficient than deposits.

Westhuizen (2007) used Data Envelopment Analysis (DEA) to estimate the monthly technical and scale efficiency for the four largest banks over a period of 36 months in South Africa. The study found that Bank B appears to be the most techni- 
cally efficient bank. However, it does not mean this bank fully efficient as it is operating under increasing return to scale zone, implying that it was operating at a scale that is too small. Bank $\mathrm{C}$ has an average technical efficiency estimate 0.951 (inputoriented), followed by Bank A with an average technical efficiency estimate of 0.917 . Bank D could at no time during the sample period, be regarded as being fully technically efficient. The technical efficiency estimates range from 0.751 to 0.900 with an average value of 0.806 (input-oriented) and from 0.758 to 0.895 with an average value of 0.809 (output-oriented). This bank operated mainly in the region of decreasing return to scale implying that it was operating at a scale that was too large. Westhuizen (2007) concluded that from an inputoriented perspective, all four banks could reduce their inputs without reducing their outputs.

Studeis on bank efficiency in Indonesia are relatively scarce. Only in recent years some of them emerged. Hadad et. al. (2003), using DEA, investigated the efficiency level of Indonesian banks applying the asset approach. The inputs used in the studies are labor cost, capital cost and interest expenses. For the output, loan disbursed both for related and unrelated parties and securities are used. The study found that joint venture bank is the most efficient bank. In term of merger, banks are found to be more efficient after the merger.

Abidn (2007), using DEA, investigated the level of efficiency among commercial banks in Indonesia. The inputs used are deposits, interest and other expenses. The outputs are loan, interest income and other incomes. In conclusion, state banks are found to be more efficient than private and regional ones. Similar to Hauner (2004), bigger banks are more efficient. However, for regional banks, there is a tendency of diseconomies of scale.

Almost all studies on bank efficiency focus on the commercial banks. Literatures focusing on rural banks are scarce. One of the study is done by Desrochers \& Lamberte (2003) on rural banks in the Philippines. The study found that agency costs significantly reduce the cost efficiency of Cooperative Rural Bank (CRB). Corporate governance is important to increase efficiency but less important that agency cost. Managers' compensation significantly improves cost efficiency and it is in accordance with the theory of asymmetric information or expense preference theory. When the compensation is related to expenses or profit, managers tend to reduce expense. The study also found that rural CRB are the most profit efficient as they can charge higher fees to borrowers. However, Big CRB was found to have the lowest average cost efficiency. This indicates the existent of diseconomies of scale.
A study on rural banks efficiency conducted by Office of Bank Indonesia Kediri (2008) also found very interesting result. In terms of cost efficiency, rural banks owned by regional government are more efficient (85.69 percent) compared to privately owned (83.61 percent) and cooperative (78.31 percent) banks. It means cooperative rural banks are least efficient. Statistically there is no difference in cost efficiency among banks operating in different regency. However, there is variability on its mean value among regions. Rural banks operating in Nganjuk have the most cost efficiency level (97.12 percent). The most inefficient rural bank is operating in Magetan as its efficiency level is 52.36 percent.

In terms of asset size, rural banks under IDR 10 billion (USD 1 millions) are less efficient compared to rural banks that have assets exceeding USD 1 million for all efficiency measures. Banks with assets less than USD 1 million have average cost eficiency of 80.65 percent, while rural banks with assets equal to or more than USD 1 million have an average efficiency level of 88.8 percent. It means that there is an 8 percent difference. In terms of soundness rating, there is no correlation towards its efficiency. It is because most of banks are operating at sound level. Asset size is the most important determinant of bank efficiency and the only significant variable found in this study.

\section{Methodology}

In this study we employed the non-parametric measure, the DEA. It is non-parametric because it requires no assumption on the shape or parameters of the underlying production function. DEA is a linear programming technique based on the pioneering work of Farrell's efficiency measure (1957), to measure the different efficiency of decision-making units (DMUs). Assuming the number of DMUs is $s$ and each DMU uses $m$ inputs and produces $n$ outputs. Let $D M U_{k}$ be one of $s$ decision units, $1 \leq k \leq s$. There are $m$ inputs which are marked with $(i=1, \ldots, m)$, and $n$ outputs marked with $Y(j=1, \ldots ., n)$. The efficiency equals the total outputs divided by total inputs. The efficiency of $D M U_{k}$ can be defined as follows:

$$
\sum_{j=1}^{n} u_{j} Y_{j}^{k}
$$

The efficiency of $D M U_{k \ldots \ldots \ldots . . .}=$

$$
\sum_{i=1}^{m} v_{i} X_{i}^{k}
$$

$X_{i}^{k}, Y_{j}^{k} \geq 0, i=1, \ldots, m, j=1, \ldots, n, k=1, \ldots, s$

$u_{j}, v_{i} \geq 0, i=1, \ldots, m, j=1, \ldots, n$. 
The DEA program enables one to find the proper weights which maximize the efficiency of DMU and calculates the efficiency score and frontier. The CCR model originated by Charnes et al. (1978), has led to several extensions, most notably the BCC model by Banker et al. (1984). The CCR and BCC models can be divided into two terms; one is the input oriented model, the other is the output oriented model. The input orientation seeks to minimize the usage of inputs given a fixed level of output while the output orientation maximizes the level of output for a given level of inputs. The CCR model assumes constant returns to scale (CRS) which means one unit input can get fixed value of output. The BCC model assumes variables returns to scale (VRS).

In this study we chose the input oriented model and used a dual problem model to solve the problems. The CCR dual model is as follows:

$$
\begin{aligned}
& \operatorname{Min} \theta-\varepsilon\left[\sum_{i=1}^{m} s_{i}^{-}+\sum_{k=1}^{n} s_{j}^{+}\right] \\
& \text {s.t. } \quad \sum_{i=1}^{s} \cdot \lambda_{r} x_{i}^{r}-\theta X_{j}^{k}+S_{i}^{-}=0 \quad i=1, \ldots, m \\
& \qquad \sum_{i=1}^{s} . \lambda_{r} Y_{j}^{r}-S_{i}^{+}=Y_{j}^{r} \\
& \lambda_{r} \geq 0 \quad r=1, \ldots, s, \\
& S_{i}^{-} \geq 0 \quad i=1, \ldots, m, \\
& S_{j}^{+} \geq 0 \quad j=1, \ldots, n,
\end{aligned}
$$

where

$\theta$ is the efficiency of DMU;

$S_{j}^{-}$is the slack variable which represents the input excess value;

$S_{j}^{+}$is the surplus variable represents the output shortfall value;

$\varepsilon$ is a non-Archimedean number which represents a very small constant;

$\lambda_{r}$ means the proportion of referencing $D M U_{r}$ when measure the efficiency of $D M U_{k}$.
If the constraint below is adjoined, the CCR dual model is known as the BCC model:

$\sum_{r=1}^{s} \lambda_{r}=1$

Equation (3) frees CRS and makes the BCC model to be VRS. For the measurement of efficiency, the CCR model measures overall efficiency (OE) of a DMU, and the BCC model can measure both the pure technical efficiency (PTE) and scale efficiency (SE) of the DMU. The relationship of OE, PTE and $\mathrm{SE}$ is as the equation (4) below:

$\mathrm{OE}=\mathrm{PTE} X \mathrm{SE}$.

DEA technique has been applied successfully as a performance measurement tool in many fields including the manufacturing sector, hospitals, pharmaceutical firms, banks, education and transportation.

In this study, an input orientation as opposed to output orientation has been adopted.

\section{Data and specification of bank inputs and outputs}

Data for 41 rural banks was taken from financial report sent to Rural Bank Association Office, East Java. As it is not obliged to send the financial report to the office, most of the banks do not do so. Banks that send reports two year consecutively are set as sample. Exception is BPR Kudamas which, for 2007, was excluded as this bank experienced a difficulty due to external operational risk event.

This study uses the intermediation approach to define bank inputs and outputs. Accordingly, one out-

\begin{tabular}{|c|c|c|c|c|c|}
\hline & Mean & Median & Std. deviation & Minimum & Maximum \\
\hline \multicolumn{6}{|c|}{2006} \\
\hline Y & 12825681.39 & 4320036 & 32023596.72 & 703393 & 190712745 \\
\hline$X_{1}$ & 13276079.46 & 2810119 & 39554620.44 & 216388 & 240059168 \\
\hline$X_{2}$ & 3599218.415 & 1248585 & 8856552.748 & 187351 & 55323893 \\
\hline \multicolumn{6}{|c|}{2007} \\
\hline$Y$ & 15820427.53 & 4427091.50 & 39790200.94 & 398410.00 & 219388955.00 \\
\hline$X_{1}$ & 15825144.9 & 3070849 & 44171269.19 & 225589 & 253098347 \\
\hline$x_{2}$ & 3971102.5 & 1482662.5 & 9784971.577 & 166396 & 60090782 \\
\hline
\end{tabular}
put and two inputs are used as follows:

\begin{tabular}{|c|l|}
\hline \multicolumn{1}{|c|}{ Output } & \multicolumn{1}{c|}{ Input } \\
\hline Y: Total earning sssets & $\begin{array}{l}\mathrm{X}_{1}: \text { Total deposits } \\
\mathrm{X}_{2}: \text { Total overhead expenses }\end{array}$ \\
\hline
\end{tabular}

Table 2 presents the descriptive statistics of output and inputs used in the study.

Table 2. Descriptive statistics for input and output, 2006 and 2007

(in million rupiahs)

Notes: $\mathrm{Y}=$ Total earning assets, $\mathrm{X}_{1}=$ Total deposits, $\mathrm{X}_{2}=$ Total operating expenses. 


\section{Findings}

All computations were performed using DEA Frontier program. The efficiency of the rural banks was first examined by applying the DEA approach for each year by using a common frontier. We then examine the efficiency of each rural bank for 2006 and 2007. Table 3 reports the means, standard deviations and extreme values of the various efficiency scores for the years under investigation.

Based on the constructed frontiers, rural banks exhibited a mean overall efficiency score of 60.6 per- cent in 2006, decreased to 58.3 percent in 2007. The average scale efficiency is 88 percent in 2006 and 84.6 percent in 2007. These mean that the minimum efficient scale is less than 12 percent in 2006 and 15 percent in 2007 on average. Using these estimates we can identify the major source of overall wasting resources (inputs), i.e. overall technical efficiency. The average pure technical efficiency is 69.9 percent in 2006 and 70.5 percent in 2007. It is apparent from Table 3 that for both years, pure technical inefficiency dominates scale inefficiency for Indonesian rural banks.

Table 3. Descriptive statistics of the DEA efficiency measures, 2006 and 2007

\begin{tabular}{|l|c|c|c|c|c|c|}
\hline \multirow{2}{*}{} & \multicolumn{3}{|c|}{2006} & \multicolumn{3}{c|}{2007} \\
\cline { 2 - 7 } & OE & PTE & SE & OE & PTE & SE \\
\hline Mean & 0.606 & 0.699 & 0.880 & 0.583 & 0.705 & 0.846 \\
\hline Median & 0.555 & 0.628 & 0.934 & 0.586 & 0.704 & 0.915 \\
\hline Standard deviation & 0.184 & 0.213 & 0.126 & 0.187 & 0.224 & 0.143 \\
\hline Kurtosis & -0.020 & -1.166 & 1.559 & -0.125 & -1.297 & 2.567 \\
\hline Skewness & 0.768 & 0.307 & -1.425 & 0.570 & -0.006 & -1.570 \\
\hline Minimum & 0.281 & 0.303 & 0.464 & 0.257 & 0.275 & 0.382 \\
\hline Maximum & 1.000 & 1.000 & 1.000 & 1.000 & 1.000 & 1.000 \\
\hline
\end{tabular}

Notes: $\mathrm{OE}=$ Overall efficiency, $\mathrm{PTE}=$ Pure technical efficiency, $\mathrm{SE}=$ Scale efficiency.

This implies that during the period under investigation rural banks have been inefficient in controlling their costs rather than operating at the wrong scale of operations. This happened when government increased fuel price three times, and the total increase was 63 percent. These inhibit increase on the inflation rate and all costs such as personnel and operational costs subsequently increase in dramatically. This ends in cost incremental to all banks. Furthermore, the policy of the central bank to increase reference rate made banks increase deposit, at the same time they could not increase interest on loan.

The results also show large variations in overall efficiency levels with the least efficient level of 28.1 percent to the most efficient bank with 100 percent in 2006 and with the least efficient level of 25.7 percent to 100 percent in 2007 for the most efficient bank. This result confirms previous study by Bank Indonesia Kediri on the variability of cost efficiency level among rural banks.

Turning to the results obtained for each individual rural bank (Table 4 and Table 5), we observe that three banks are fully efficient in 2006 and 2007. These banks are: Babat Lestari, Kalimasada \& Artha Waringin Jaya. The most inefficient bank in 2006 is Balung Artha Guna with an average overall efficiency of 28.1 percent. On the other hand, the most inefficient bank in 2007 is Kabupaten Dati II Mojokerto with an average overall efficiency of 25.7 percent.

Table 4. Mean of technical and scale efficiencies of individual banks, 2006

\begin{tabular}{|c|l|c|c|c|c|l|c|c|c|}
\hline No.0 & \multicolumn{1}{|c|}{ Bank } & OE & TE & SE & No.0 & Bank & OE & TE & SE \\
\hline 1 & Balongpanggang Sentosa & 0.382 & 0.406 & 0.941 & 22 & Balung Artha Guna & 0.281 & 0.303 & 0.929 \\
\hline 2 & Babat Lestari & 1.000 & 1.000 & 1.000 & 23 & Intan Nasional & 0.411 & 0.422 & 0.974 \\
\hline 3 & Nusamba Brondong & 0.555 & 0.612 & 0.906 & 24 & Jember Lestari & 0.955 & 1.000 & 0.955 \\
\hline 4 & Mitra Dhanaceswara & 0.555 & 0.592 & 0.937 & 25 & Jawa Timur & 0.464 & 1.000 & 0.464 \\
\hline 5 & BPR Rajekwesi & 0.740 & 0.740 & 0.999 & 26 & Taman Dhana & 0.630 & 0.675 & 0.934 \\
\hline 6 & Buana Dana Makmur & 0.696 & 0.703 & 0.991 & 27 & Terusan Jaya & 0.619 & 0.628 & 0.986 \\
\hline 7 & Delta Artha & 0.675 & 1.000 & 0.675 & 28 & Artha Pamenang Pare & 0.395 & 0.564 & 0.700 \\
\hline 8 & Rukun Karya Sari & 0.605 & 0.616 & 0.981 & 29 & Toeloengredjo Dasa Nusantara & 0.531 & 0.610 & 0.869 \\
\hline 9 & Surasari Hutama & 0.477 & 0.650 & 0.734 & 30 & Hasta Krida Jaya & 0.668 & 0.696 & 0.960 \\
\hline 10 & Kalimasada & 1.000 & 1.000 & 1.000 & 31 & Arta Kencana & 0.711 & 1.000 & 0.711 \\
\hline 11 & Artha Senapati & 0.658 & 0.747 & 0.881 & 32 & Pemda Kabupaten Kediri & 0.585 & 0.755 & 0.774 \\
\hline 12 & Tanggul Arto & 0.502 & 0.543 & 0.925 & 33 & Rukun Makmur & 0.556 & 0.777 & 0.715 \\
\hline 13 & Puriseger Sentosa & 0.935 & 1.000 & 0.935 & 34 & Wijaya Kusuma & 0.442 & 0.475 & 0.931 \\
\hline 14 & Putera Madura & 0.692 & 1.000 & 0.692 & 35 & Pemda Kota Madiun & 0.832 & 1.000 & 0.832 \\
\hline 15 & Kabupaten Dati II Mojokerto & 0.808 & 0.865 & 0.934 & 36 & Handalniaga Bumindo & 0.461 & 0.492 & 0.938 \\
\hline
\end{tabular}


Table 4 (cont.). Mean of technical and scale efficiencies of individual banks, 2006

\begin{tabular}{|c|l|c|c|c|c|l|c|c|c|}
\hline No.o & \multicolumn{1}{|c|}{ Bank } & OE & TE & SE & No.0 & Bank & OE & TE & SE \\
\hline 16 & Sentral Arta Asia & 0.389 & 0.565 & 0.689 & 37 & Candisaka Arta & 0.538 & 0.568 & 0.948 \\
\hline 17 & Bangil Idaman & 0.468 & 0.502 & 0.933 & 38 & Bhapertim Persada & 0.549 & 0.578 & 0.949 \\
\hline 18 & Delta Bondowoso & 0.433 & 0.445 & 0.974 & 39 & Ploso Saranaartha & 0.553 & 0.567 & 0.975 \\
\hline 19 & Artha Waringin Jaya & 1.000 & 1.000 & 1.000 & 40 & Kudamas & 0.442 & 0.501 & 0.882 \\
\hline 20 & Bintang Mas Maesan & 0.656 & 1.000 & 0.656 & 41 & Surya Arthaguna Abadi & 0.553 & 0.593 & 0.932 \\
\hline 21 & Artha Tunasmukti & 0.436 & 0.462 & 0.942 & & & & & \\
\hline
\end{tabular}

Notes: $\mathrm{OE}=$ Overall efficiency, $\mathrm{TE}=$ Pure technical efficiency, $\mathrm{SE}=$ Scale efficiency.

Table 5. Mean of technical and scale efficiencies of individual banks, 2007

\begin{tabular}{|c|l|c|c|c|c|l|c|c|c|}
\hline No.0 & \multicolumn{1}{|c|}{ Bank } & OE & TE & SE & No.0 & Bank & OE & TE & SE \\
\hline 1 & Balongpanggang Sentosa & 0.372 & 0.390 & 0.954 & 22 & Balung Artha Guna & 0.747 & 0.793 & 0.942 \\
\hline 2 & Babat Lestari & 1.000 & 1.000 & 1.000 & 23 & Intan Nasional & 0.519 & 0.560 & 0.926 \\
\hline 3 & Nusamba Brondong & 0.528 & 0.634 & 0.832 & 24 & Jember Lestari & 0.658 & 0.734 & 0.897 \\
\hline 4 & Mitra Dhanaceswara & 0.653 & 0.711 & 0.918 & 25 & Jawa Timur & 0.437 & 1.000 & 0.437 \\
\hline 5 & BPR Rajekwesi & 0.689 & 0.735 & 0.938 & 26 & Taman Dhana & 0.733 & 0.888 & 0.826 \\
\hline 6 & Buana Dana Makmur & 0.395 & 0.420 & 0.941 & 27 & Terusan Jaya & 0.417 & 0.527 & 0.790 \\
\hline 7 & Delta Artha & 0.632 & 1.000 & 0.632 & 28 & Artha Pamenang Pare & 0.398 & 0.587 & 0.678 \\
\hline 8 & Rukun Karya Sari & 0.792 & 1.000 & 0.792 & 29 & Toeloengredjo Dasa Nusantara & 0.478 & 0.570 & 0.839 \\
\hline 9 & Surasari Hutama & 0.499 & 0.697 & 0.716 & 30 & Hasta Krida Jaya & 0.611 & 0.653 & 0.935 \\
\hline 10 & Kalimasada & 1.000 & 1.000 & 1.000 & 31 & Arta Kencana & 0.710 & 1.000 & 0.710 \\
\hline 11 & Artha Senapati & 0.773 & 0.945 & 0.818 & 32 & Pemda Kabupaten Kediri & 0.609 & 0.868 & 0.702 \\
\hline 12 & Tanggul Arto & 0.390 & 0.417 & 0.936 & 33 & Rukun Makmur & 0.564 & 0.600 & 0.939 \\
\hline 13 & Puriseger Sentosa & 0.821 & 0.954 & 0.861 & 34 & Wijaya Kusuma & 0.437 & 0.462 & 0.946 \\
\hline 14 & Putera Madura & 0.382 & 1.000 & 0.382 & 35 & Pemda Kota Madiun & 0.628 & 0.845 & 0.743 \\
\hline 15 & Kabupaten Dati II Mojokerto & 0.257 & 0.275 & 0.933 & 36 & Handalniaga Bumindo & 0.409 & 0.443 & 0.923 \\
\hline 16 & Sentral Arta Asia & 0.320 & 0.460 & 0.695 & 37 & Candisaka Arta & 0.652 & 0.702 & 0.928 \\
\hline 17 & Bangil Idaman & 0.542 & 0.578 & 0.937 & 38 & Bhapertim Persada & 0.412 & 0.431 & 0.957 \\
\hline 18 & Delta Bondowoso & 0.429 & 0.446 & 0.962 & 39 & Ploso Saranaartha & 0.687 & 0.722 & 0.951 \\
\hline 19 & Artha Waringin Jaya & 1.000 & 1.000 & 1.000 & 40 & Kudamas & NA & NA & NA \\
\hline 20 & Bintang Mas Maesan & 0.711 & 1.000 & 0.711 & 41 & Surya Arthaguna Abadi & 0.634 & 0.706 & 0.898 \\
\hline 21 & Artha Tunasmukti & 0.408 & 0.447 & 0.913 & & & & \\
\hline
\end{tabular}

Notes: $\mathrm{OE}=$ Overall efficiency, $\mathrm{TE}=$ Pure technical efficiency, $\mathrm{SE}=$ Scale efficiency.

\section{Conclusions}

In this present study we have estimated the technical and scale efficiency of rural banks in Indonesia for the period of 2006 and 2007. We have used inputoriented Data Envelopment Analysis with variable returns to scale. As in most previous studies on bank efficiency, we find that on average, bank deviates substantially from the best-practice frontier. The technical efficiency for the whole sample on average was 60.6 percent in 2006 and 58.3 percent in 2007 suggesting an input waste of 39.4 percent and 41.7 percent, respectively. Overall, the level of efficiency has decreased over the two-year period.
The results indicate that for both years, 2006 and 2007, pure technical inefficiency dominates scale inefficiency for Indonesian rural banks. This implies that during the period under investigation rural banks have been inefficient in controlling their costs rather than operating at the wrong scale of operations.

As a caveat, the results should be interpreted with great caution since previous researches differ substantially across different estimation procedures. Further study should use other estimation approaches looking at the cost and profit efficiency, and results, thus, can be compared.

\section{References}

1. Abdin, Z. (2007). Kinerja Efisiensi Pada Bank Umum, Proceeding Pesat (Psikologi, Ekonomi, Sastra, Arsitek \& Sipil). Vol. 2, ISSN : 1858-2559.

2. Berger, A. \& Humphrey, D. (1997). "Efficiency of Financial Institutions: International Survey and Directions for Future Research", European Journal of Operational Research, 98, 175-212.

3. Coelli, T. (1996). "A Guide to DEAP Version 2.1: A Data Envelopment Analysis (Computer) Program", Center for Efficiency and Productivity Analysis, Working Paper 96/08 (Armidale, New England: University of New England). 
4. Desrochersa, M. \& Lamberte, M. (2003). Efficiency and Expense Preference in Philippines' Cooperative Rural Banks, CIRPEE WORKING PAPER No. 03-21.

5. Farrell, M.J. (1957). "The Measurement of Productive Efficiency”, Journal of the Royal Statistical Society, $253-81$.

6. Favero, C.A. \& Papi, L. (1995). A Technical Efficiency and Scale Efficiency In The Italian Banking Sector: A Non-Parametric Approach, Applied Economics, 27: 385-395.

7. Hadad, M., Santoso, W., Ilyas, D. \& Mardunegara, E. (2003). “Analisa Effisiensi Industri Perbankan Indonesia: Penggunaan Metode Non Paramerik, Data Envelopment Analysis". Working Paper, Bank Indonesia.

8. Hauner, D. (2004). Explaining Efficiency Differences Among Large German and Austrian Banks, International Monetary Fund WP/04/140.

9. Jahanshahlooa, G. R. et al. (2008). Ranking Units in Data Envelopment Analysis by Pessimistic Weights, Paper presented on the International Mathematical Forum, 3, 2008, no. 29, 1451-1455.

10. Resti, A. (1997). Evaluating the cost efficiency of the Italian banking system: what can be learned from the join application of parametric and non parametric techniques, Journal of Banking and Finance, 21, 221-2250.

11. Westhuizen, G. (2007). Estimating Technical And Scale Efficiency Of Banks Using Balance Sheet Data: A South African Case, Working paper, School for Economic Sciences North-West University Vaal Triangle Campus, Vanderbijlpark, South Africa.

12. Office of Bank Indonesia Kediri (2008). Rural Banks Efficiency and its Determinant, Research report.

13. Bank Indonesia (2008). Report to Parliament on the Role and Responsibility of Bank Indonesia, $2^{\text {nd }}$ Quarter. 